\title{
Deformation behaviour of granular column reinforced by geosynthetic encasement
}

\author{
Le Quan ${ }^{*}$, Vo Dai Nhat, Pham Tien Bach, Nguyen Viet Ky
}

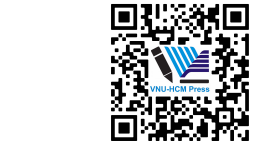

Use your smartphone to scan this QR code and download this article
Faculty of Geology and Petroleum Engineering, Ho Chi Minh City University of Technology, Vietnam

Correspondence

Le Quan, Faculty of Geology and Petroleum Engineering, Ho Chi Minh City University of Technology, Vietnam

Email: quanlepvep@gmail.com

History

- Received: 8-10-2020

- Accepted: 19-5-2021

- Published: 25-5-2021

DOI : 10.32508/stdjet.v4i2.777

\section{Check for updates}

\section{Copyright}

(c) VNU-HCM Press. This is an openaccess article distributed under the terms of the Creative Commons Attribution 4.0 International license.

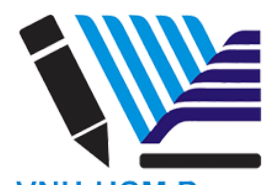

VNU-HCM Press

\begin{abstract}
In Vietnam, the overpopulation and strong economic development require the synchronous development of infrastructure such as roads, urban areas, industrial parks, export processing zones, etc. With such requirements, the development of land fund for infrastructure construction is an indispensable need. Meanwhile, the appropriate land fund is very limited. Therefore, the land fund must be developed for areas with little value for agriculture, such as swamps, estuaries, and coastal areas, etc. These areas often have weak geological conditions; hence, to meet the requirements of infrastructure construction on the soft ground, it is necessary to carry out soil improvement to ensure load bearing capacity, total settlement, and consolidation settlement but still ensuring economic effectiveness. Beside several conventional methods widely used for soft soil improvement in order to increase bearing capacity and accelerate consolidation settlement of the ground, geosynthetic reinforced granular column is one of the new methods that has been applied to improving soft ground in designing practice in the recent years due to the many advantages of this method compared with other methods. In this paper, based on the unit cell model, the authors research on deformation behavior of granular column reinforced by geosynthetic encasement through the analytical analysis by varying external loadings corresponding to column diameter, stiffness of geosynthetic encasement. The settlements of a single geosynthetic encased granular column and load bearing capacity of the composite foundation are calculated on geological conditions of Ash Pond Area of Song Hau 1 Thermal Power Plant located in Hau Giang Province. The relationship between settlement and load bearing capacity with external loadings for different column diameters and geosynthetic stiffnesses are shown schematically. Other considerations related to factor of safety are also presented. The future researches are also proposed.
\end{abstract}

Key words: Geosynthetic encased granular column, soft soil, settlement, vertical stress

\section{INTRODUCTION}

There are many methods that have being used to improve soft soil such as granular column, vertical drain, vacuum preloading, limestone column, soil cement column, concrete column, etc. Recently, scientists have proposed a method for soft soil improvement by geosynthetic encased granular column. This is an extension of the stone column method. This method has advantages over granular column due to geosynthetic granular column derives its loading capacity through two factors including i) passive pressure from the surrounding soft soil owing to bulging of granular column ii) additional lateral confinement by considering the hoop tensile force in the geosynthetic encasement. Furthermore, geosynthetic prevents clogging of the granular aggregate by surrounding soft soil, preserves the drainage and frictional properties of the granular soils as described by Raithel et al. $2002^{1}$, Alexiew et al. $2005^{2}$, Brokemper et al. $2006^{3}$, Kempfert and Gebreselassie $2006^{4}$, Tandel Y.K et al. $2014^{5}$, Domenico Gioffrè et al. $2016^{6}$.
In this study, the authors use a simple analytical method developed to estimate the settlement and bearing capacity of an individual geosynthetic encased granular column and its composite foundation due to the possible bulging failure mechanism proposed by Murugesan and Rajagopal $2010^{7}$. The authors investigated the importance of column diameter, tensile stiffness of geosynthetic to the settlement and bearing capacity. The settlement and bearing capacity are calculated based on geological conditions of Ash Pond Area of Song Hau 1 Thermal Power Plant located in Hau Giang province.

\section{METHODOLOGY}

In this paper, the authors apply the unit cell model introduced by Raithel and Kempfert $2000^{8}$. The model is used to calculate settlement and bearing capacity of geosynthetic encased granular column by using analytical solution. The problem is tested in a real project in Viet Nam. The results then are shown and discussed. 


\section{ANALYTICAL SOLUTION}

\section{Settlement}

The proposed analytical method by Raithel and Kempfert $2000^{8}$, for the settlement of a geosynthetic encased granular column reinforced foundation is based on a unit cell model as present in Figure 1. This model considers the contribution of geosynthetic encasement by providing additional confinement to the column ${ }^{9}$.

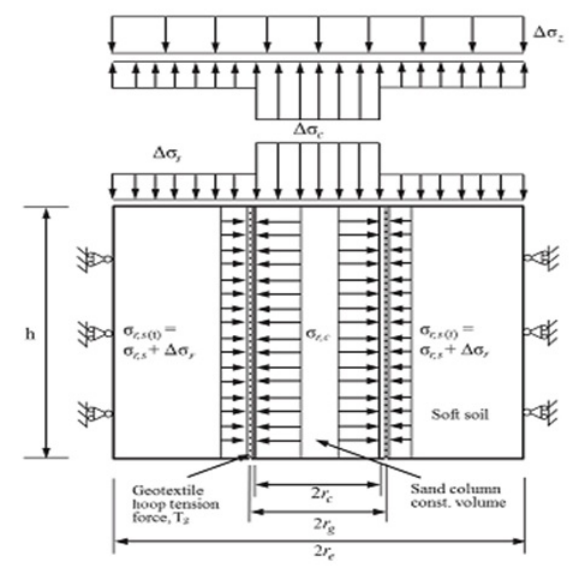

Figure 1: Unit cell model for a geosynthetic encased column $^{9}$

The radial stresses in soil and column are given by:

$$
\begin{aligned}
& \triangle \sigma_{r, c}=\triangle \sigma_{c} K_{a, c}+\sigma_{z 0, c} K_{a, c} \\
& \triangle \sigma_{r, s}=\triangle \sigma_{s} K_{a, s}+\sigma_{z 0, s} K_{a, s}
\end{aligned}
$$

The radial stress on the geosynthetic encasement is given by:

$$
\triangle \sigma_{r, g}=J \frac{\triangle r_{c}}{r_{g}^{2}}
$$

The radial stress difference between the column and the soil which represents the partial mobilization of the passive earth pressure in the surrounding soft soil is computed by Jie-Han $2015^{9}$ :

$$
\triangle \sigma_{r}=\sigma_{r, c}-\sigma_{r, s}-\sigma_{r, g}
$$

The radial displacement, $\Delta \mathrm{rc}$ is computed by:

$$
\triangle r_{c}=\frac{\triangle \sigma_{r}}{E^{*}}\left(\frac{1}{a_{S}}-1\right) r_{c}
$$

The settlement of the soft soil, Ssl is computed by:

$$
S_{s l}=\left[\frac{\triangle \sigma_{s}}{D_{s}}-\frac{2}{E^{*}}\left(\frac{v_{S}}{1-v_{S}}\right) \triangle \sigma_{r}\right] h
$$

The settlement of the column, $\mathrm{Scl}$ is computed by:

$$
S_{c l}=\left[1-\frac{r_{c}^{2}}{\left(r_{c}+\Delta r_{c}\right)^{2}}\right] h
$$

Here:

$\sigma_{z 0, c}=$ overburden stress of the column

$\sigma_{z 0, s}=$ overburden stress of the soil

$\sigma_{r, c}=$ radial stress in the column by the overburden stress of the column

$\sigma_{r, s}=$ radial stress in the soil by the overburden stress of the column

$\sigma_{r, g}=$ radial stress on the geosynthetic encasement (additional confining stress)

$K_{a, c}=$ active earth pressure coefficient in the column

$K_{0, s}=$ at-rest earth pressure coefficient in the soil

$J=$ tensile stiffness of geosynthetic encasement

$h=$ thickness of the soil or length of the column

$r_{g}=$ radius of the geosynthetic encasement

$r_{C}=$ radius of the column

$E^{*}=$ derive from elastic modulus of the soil

The details analytical solution for settlement of the column can be found in Jie-Han $2015^{9}$.

\section{Bearing capacity}

Murugesan and Rajagopal $2010^{7}$ considered an additional confinement by geosynthetic encasement for an ultimate bearing capacity of an individual column due to possible bulging failure with a bulging length of four times the column diameter as follow ${ }^{9}$ :

$$
q_{u l t, c}=\left(\sigma_{r 0}+4 c_{u}+\sigma_{r, g}\right) K_{p}
$$

And the ultimate bearing capacity of the composite foundation based on the ultimate bearing capacities of the soil and the individual column, and the area replacement ratio using equation is given as follows ${ }^{9}$ :

$$
q_{u l t}=q_{u l t, c} a_{s}+q_{u l t, s}\left(1-a_{s}\right)
$$

The factor of safety can be computed by:

$$
F S=\frac{q_{u l t}}{p}
$$

Here:

$\sigma_{r, 0}=$ radial soil stress induced by the overburden stress at the middle point of the column bulging length.

$K_{p}=$ coefficient of passive earth pressure of the column.

$c_{u}=$ undrained shear strength of the soil.

$q_{u l t, s}=$ ultimate bearing capacity of the surrounding soil.

$=$ external applied load

$a_{s}=$ area replacement ratio.

The details analytical solution for bearing capacity can be found in Jie-Han $2015^{9}$. 


\section{CASE STUDY}

\section{An introduction of project}

The Song Hau 1 Thermal Power Plant is located in the Song Hau Power Complex situated in Hau Giang Province. The layout plan of the complex is an approximately occupied area of the total 115.2 hectares. The facilities can be divided into several blocks in accordance with the location of the plant facilities, including the main power plant island, Coal storage yard and balance of Plant, switchyard area, and ash pond area and various buildings, etc. This study presents the ground improvement analysis of soft soil ground under the dyke of the ash pond. The required service loading is $20 \mathrm{kN} / \mathrm{m}^{2}$ and $5 \mathrm{~m}$ height for Dyke after completion of soft soil improvement. The maximum allowable total settlement is $2.3 \mathrm{~m}$. The allowable factor of safety for bearing capacity of the composite foundation is greater than $2^{10,11}$.

\section{Geological Conditions}

A series of calculation was carried out based on material parameters of column presented in Table 1 and soil parameters presented in Table $2^{10,11}$ for Ash Pond Area.

\section{Results and discussion}

\section{Effect of diameter of column}

It can be seen in Figure 2 the stress - settlement response of $0.6 \mathrm{~m}$ diameter. The settlement is found to be increasing corresponding to an increase of vertical stress. The settlement at stress of $100 \mathrm{kN} / \mathrm{m}^{2}$ is found lower than 2 to 5 times correspondingly to vertical stress at $200,300,400 \mathrm{kN} / \mathrm{m}^{2}$.

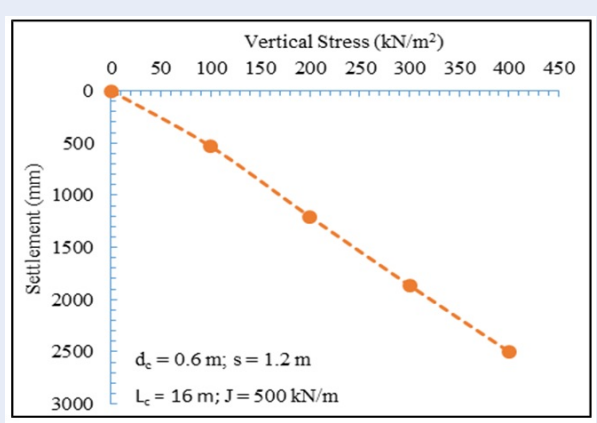

Figure 2: Stress - Settlement response of $0.6 \mathrm{~m}$ diameter

Figure 3 shows the relationship between the vertical stresses - factor of safety against bearing failure of the composite foundation of $0.6 \mathrm{~m}$ diameter. The factor of safety decreases with increasing the vertical stress, respectively. The factor of safety reduces correspondingly to an increase of the settlement of the column and vice versa. It is found that the factor of safety at $100 \mathrm{kN} / \mathrm{m}^{2}$ higher than 2, 3, 4 times of factor of safety corresponding to stresses at 200, 300, 400 $\mathrm{kN} / \mathrm{m}^{2}$. It can be seen in Figure 3 that vertical stress is found lower than $230 \mathrm{kN} / \mathrm{m}^{2}$ leading to factor of safety higher than 2 times and meeting requirements of the project.

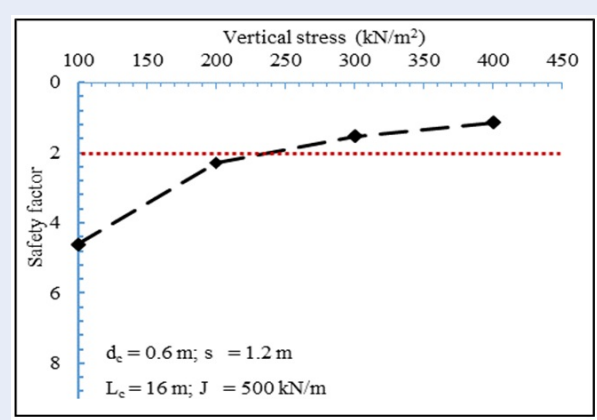

Figure 3: Stress - Safety factor response

Figure 4 shows the settlement - stress responses of 0.6 $\mathrm{m}, 0.8 \mathrm{~m}, 1.0 \mathrm{~m}$ diameter columns and tensile stiffness of $\mathrm{J}=500 \mathrm{kN} / \mathrm{m}$. The settlements have also shown similar trends of increasing with an increase of vertical stress. The settlement of column reduces with an increase of the diameters at the same vertical stress and tensile stiffness of geosynthetic.

As indicated in Figure 4, the settlement of $0.6 \mathrm{~m}$ diameter column is found higher than settlement of $0.8 \mathrm{~m}$ diameter column from 2 down to 1.6 times and higher than settlement of $1.0 \mathrm{~m}$ diameter column from 6.6 down to 3 times. The settlement of $0.8 \mathrm{~m}$ diameter column is higher than settlement of $1.0 \mathrm{~m}$ diameter column from 3.2 down to 1.9 times.

Figure 5 shows the comparative relationship between the vertical stress - factor of safety against bearing failure of the composite foundation with $0.6 \mathrm{~m}, 0.8 \mathrm{~m}, 1.0$ $\mathrm{m}$ of diameter column. The curves also show similar trends of decreasing with an increase of vertical stress. The factor of safety increases with an increase of diameter at the same vertical stress and tensile stiffness of geosynthetic. The factor of safety in case of $0.8 \mathrm{~m}$ diameter is found higher than factor of safety in case of $0.6 \mathrm{~m}$ diameter about 1.3 times. The factor of safety in case of $1.0 \mathrm{~m}$ diameter is found higher than factor of safety of $0.6 \mathrm{~m}$ about 1.7 times. The factor of safety in case of $1.0 \mathrm{~m}$ diameter is found higher than it of $0.8 \mathrm{~m}$ diameter about 1.2 times. It is shown that the column 
Table 1: Material of column and its parameters

\begin{tabular}{lllll}
\hline Material Type & $\gamma_{\mathrm{sat}}\left(\mathrm{kN} / \mathrm{m}^{3}\right)$ & $\mathrm{E}\left(\mathrm{kN} / \mathrm{m}^{2}\right)$ & $\varphi(\mathrm{o})$ & $\mathrm{v}$ \\
Coarse sand & 19.1 & 40,000 & 400 & 0.3 \\
\hline
\end{tabular}

Table 2: Soil layers and its parameters of the ground site

\begin{tabular}{lllll}
\hline Soil Type & Filling Soil & Very soft Clay & Stiff Clay & Very stiff Clay \\
Depth $(\mathrm{m})$ & 1.5 & 14.5 & 17.0 & 42.0 \\
$\gamma\left(\mathrm{kN} / \mathrm{m}^{3}\right)$ & 15.1 & 15.2 & 17.4 & 19 \\
$\mathrm{E}\left(\mathrm{kN} / \mathrm{m}^{2}\right)$ & - & 420 & - & - \\
$\mathrm{c}\left(\mathrm{kN} / \mathrm{m}^{2}\right)$ & - & 9.7 & 18.4 & 20.1 \\
$\varphi\left({ }^{0}\right)$ & - & $3^{0} 59^{\prime}$ & $10^{0} 25^{\prime}$ & $17^{0} 40^{\prime}$ \\
$\mathrm{v}$ & 0.35 & 0.35 & 0.35 & 0.35 \\
\hline
\end{tabular}

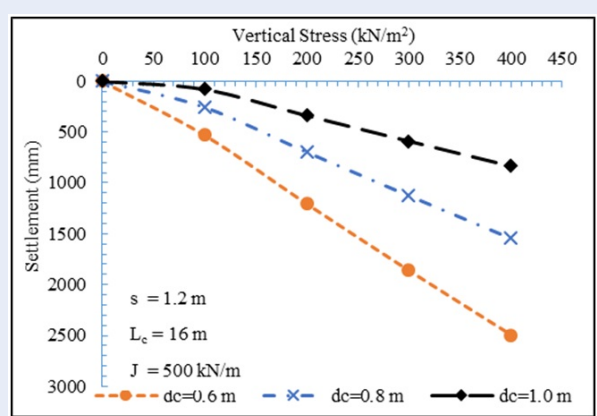

Figure 4: Settlement - Stress response for different diameters

with higher diameter will increase the bearing capacity of composite foundation. As can be seen in Figure 5 , vertical stress is found lower than $200 \mathrm{kN} / \mathrm{m}^{2}$ leading to factor of safety higher than 2 times for all curves and meeting requirements of the project.

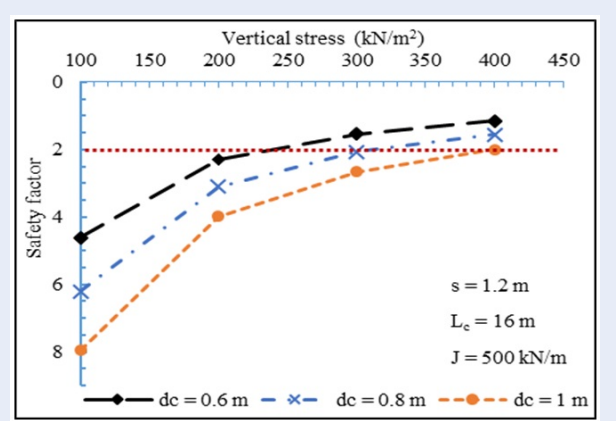

Figure 5: Stress - Safety factor response for different diameters

\section{Effect of tensile stiffness of geosynthetic}

Figure 6 shows vertical stress - settlement responses of the column for different values of tensile stiffness of $1 \mathrm{~m}$ column diameter. As can be seen, stress on column increases with an increase of tensile stiffness of geosynthetic. The hoop stress in geosynthetic increases, it leads to increasing in confining pressures in the column as described by Murugesan and Rajagopal $2006^{12}$. Hence, the column with higher tensile stiffness will induce larger confining pressures, leading to a stiffer and stronger response of the column ${ }^{5}$.

As indicated in Figure 6, the settlement of column at $500 \mathrm{kN} / \mathrm{m}$ tensile stiffness is higher than that at $1000 \mathrm{kN} / \mathrm{m}$ tensile stiffness from 1.16 to 1.2 times and higher at $1500 \mathrm{kN} / \mathrm{m}$ tensile stiffness from 1.35 to 1.4 times. The settlement of column at $1000 \mathrm{kN} / \mathrm{m}$ tensile stiffness is higher than that at $1500 \mathrm{kN} / \mathrm{m}$ tensile stiffness from 1.16 to 1.4 times. The variation of settlement slightly increases with an increase of vertical tress.

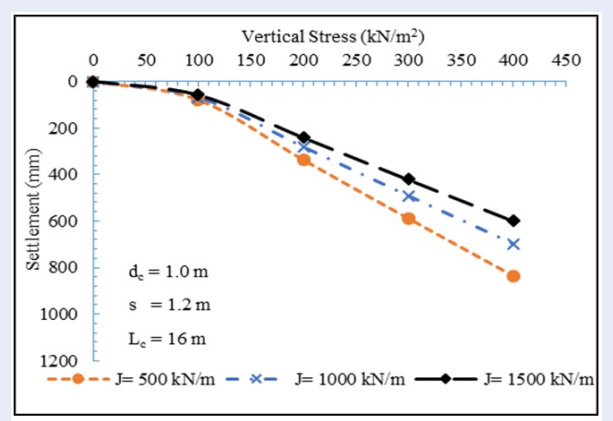

Figure 6: Settlement - Stress response for different tensile stiffness 
Figure 7 shows the relationship between the vertical stresses - factor of safety against bearing failure of the composite foundation for different tensile stiffness. The factor of safety also shows the similar trend with an increase of tensile stiffness of the column and vice versa. It is shown that the geosynthetic with higher stiffness has a higher bearing capacity of composite foundation. The factor of safety in case of $500 \mathrm{kN} / \mathrm{m}$ tensile stiffness is found lower than that of $1000 \mathrm{kN} / \mathrm{m}$ and $1500 \mathrm{kN} / \mathrm{m}$ tensile stiffness about 1.8 times and 2.6 times, respectively, corresponding to stresses at $100,200,300,400 \mathrm{kN} / \mathrm{m}^{2}$. The factor of safety of $1000 \mathrm{kN} / \mathrm{m}$ tensile stiffness is found lower than that of $1500 \mathrm{kN} / \mathrm{m}$ tensile stiffness about 1.45 times corresponding to stresses of $100,200,300,400 \mathrm{kN} / \mathrm{m}^{2}$. It is shown that the column with higher tensile stiffness of geosynthetic will increase the bearing capacity of composite foundation.

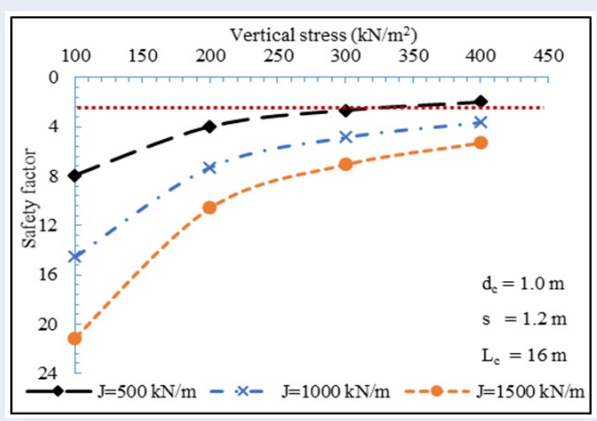

Figure 7: Stress - Safety factor response for different tensile stiffness

\section{CONCLUSIONS}

From the analytical results, some main conclusions can be taken:

- The settlement increases from 2 to 5 times while factor of safety decreases from 2 to 4 times correspondingly with an increase of vertical stress varying from 200 to $400 \mathrm{kN} / \mathrm{m}^{2}$ in case of $0.6 \mathrm{~m}$ diammeter.

- In case of diameter varying from $0.6 \mathrm{~m}$ up to $1.2 \mathrm{~m}$, the settlement of column decreases continuously from maximum of 6.6 times down to 1.6 times, respectively; factor of safety increases from 1.3 to 1.7 times correspondingly with increasing diameter of column.

- The variation of settlement slightly decreases from 1.4 to 1.16 times while factor of safety increases from 1.8 to 2.6 times for different values of tensile stiffness from 500 to $1500 \mathrm{kN} / \mathrm{m}$.
- Through this investigation, the importance role of diameter and tensile stiffness of granular column reinforcement by geosynthetic are shown.

\section{FUTURE WORK}

- Study on deformation behavior of GEC by analytical method and numerical method.

- Study on deformation behavior of GEC by considering the impact of interface area between geosynthetic and soil, geosynthetic and column.

- Study on deformation behavior of GEC by considering the effect of geosynthetic reinforcement length.

- Study on the effect of internal friction angle and cohesive of column materials to its bearing capacity.

\section{CONFLICT OF INTEREST}

The authors pledge that there are no conflicts of interest in the publication of the paper.

\section{AUTHOR CONTRIBUTION}

Le Quan presents the idea of study and discuss with Dr. Vo Dai Nhat. Besides, Le Quan carries out data collecting, computes result and writes a draft or the paper. Dr. Vo Dai Nhat checks the results, review the paper, corrects all. Pham Tien Bach supports and reviews the calculation data, input data, output data. Assoc. Prof. Dr. Nguyen Viet Ky gives some advice during researching process.

\section{REFERENCES}

1. Alexiew D, Raithel M, Kuster V. 15 years of experience with geotextile encased granular columns as foundation system. ISSMGE -TC 211 International Symposium on Ground Improvement, Brussels. 2012;

2. Alexiew D, Brokemper D, Lothspeich S. Geotextile Encased Columns (GEC): Load capacity, geotextile selection and predesign graphs. Geotechnical Special Publication, No. 130-142, Geo-Frontiers. 2005;p. 497-510. Available from: https://doi. org/10.1061/40777(156)12.

3. Brokemper D, et al. Design and construction of geotextile encased columns supporting geogrid reinforced landscape embankments; Bastions Vijfwal Houten in the Netherlands. Proceedings of the 8th International Conference on Geosynthetics, Yokohama, Japan, October. 2006;p. 889-892.

4. Kempfert HG, Gebreselassie B. Excavations and Foundation in Soft Soils. Springer - Verlag, Berlin, Germany. 2006;

5. Tandel YK, Solanki CH, Desai AK. Field behaviour geotextile reinforced sand. Geomechanics and Engineering. 2014;6(2):117. Available from: https://doi.org/10.12989/gae.2014.6.2.195.

6. Gioffrè $D$, et al. Numerical analyses of soft soil reinforced with GEC. Procedia Engineering. 2016;158:140-145. Available from: https://doi.org/10.1016/j.proeng.2016.08.419.

7. Murugesan S, Rajagopal K. Studies on the behavior of single and group of geosynthetic encased stone columns. J. Geotech. Geoenviron. Eng. 2010;136(1):13-15. Available from: https://doi.org/10.1061/(ASCE)GT.1943-5606.0000187. 
8. Raithel M, Kempfert HG. Calculation models for dam foundations with geotextile - coated sand columns. Proceeding of International Conference on Geotechnical \& Geological Engineering, GeoEng, Melbourne, Australia. 2000;p. 347-352.

9. Han J. Principles and Practice of Ground Improvement. Wiley. 2015;p. 133-155.

10. Report on soil investigation work. Song Hau 1 Thermal Power Plant project- Items: Ash Pond Area. 2016;
11. Ash Pond Area. Soil Improvement for Dyke - Song Hau 1 Thermal Power Plant project. 2016;.

12. Murugesan S, Rajagopal K. Geosynthetic encased stone columns: Numerical evaluation. Geotech. Geomembr. 2006;24(6):349-358. Available from: https://doi.org/10.1016/j.geotexmem.2006.05.001. 


\title{
Ứng xử biến dạng của cọc hạt rời bọc vải địa kỹ thuật
}

\author{
Lê Quân*, Võ Đại Nhật, Phạm Tiến Bách, Nguyễn Việt Kỳ
}

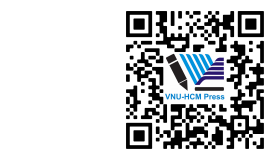

Use your smartphone to scan this QR code and download this article

\section{TÓM TÁ́T}

Tại Việt nam, sự bùng nổ dân số và phát triển mạnh mẽ của nền kinh tế đòi hỏi phải có sự phát triển đồng bộ cơ sở hạ tầng như hệ thống đường bộ, đô thị, khu công nghiệp v.v. Với nhu cầu đó, việc phát triển quỹ đất phục vụ cho phát triển cơ sở hạ tầng là tất yếu. Trong khi đó, quỹ đất còn lại rất hạn chế. Bởi vậy, phải phát triển quỹ đất ra các khu vực như đầm lây, cửa sông, ven biển v.v. Đây là các khu vực ít có giá trị về nông nghiệp, nuôi trông thủy hải sản. Các khu vực này thường có điều kiện địa chất yếu; do đó, để đảm bảo an toàn cho việc xây dựng cơ sở hạ tầng thì cần thiết phải tiến hành các biện pháp cải tạo nển đất yếu nhằm đảm bảo sức chịu tải, độ lún tổng, độ lún cố kết nhưng vẫn phải đảm bảo hiệu quả kinh tế.

Bên cạnh các phương pháp thông thường đã được sử dụng rộng rãi để cải tạo đất yếu nhằm tăng khả năng chịu tải và rút ngắn tốc độ lún cố kết của nền đất, cọc hạt rời bọc vải địa kỹ thuật là một trong những phương pháp mới được áp dụng trong thực hành thiết kế cải tạo đất yếu trong những năm gần đây nhờ các ưu điểm vượt trội của nó so với các phương pháp khác. Trong bài báo này, nhóm tác giả dựa trên mô hình lăng trụ để nghiên cứu ứng xử biến dạng của cọc hạt rời bọc vải đia kỹ thuật thông qua tính toán giải tích bằng cách thay đổi tải trong thẳng đứng của ngoại lực tương ứng với từng đường kính cọc và độ cứng của vải bọc địa kỹ thuật. Độ lún của cọc đợn và sức chịu tải của tổ hợp cọc và đất được tính toán dựa trên điêu kiện địa chất của khu vực bể chứa xỉ than Nhà máy nhiệt điện Sông Hậu 1 tại tỉnh Hậu Giang. Quan hệ giửa biến dạng lún và sức chịu tải với tác động của ngoại lực đối với các giá trị đường kính khác nhau, độ cứng của vải địa kỹ thuật khác nhau được trình bày dưới dạng đồ thi. Các vấn để liên quan đến hệ số an toàn cũng được trình bày trong bài báo. Các nghiên cứu tiếp theo trong tương lai được để xuất.

Từ khoá: cọc bọc vải địa kỹ thuật, đất yếu, độ lún, ứng xuất thẳng đứng
Khoa Kỹ thuât Địa chất và Dâu khí, Truờng Đại học Bách khoa, ĐHQG HCM, Việt Nam

Liên hệ

Lê Quân, Khoa Kỹ thuật Địa chất và Dầu khí Trường Đại học Bách khoa, ĐHQG - HCM, Việt Nam

Email: quanlepvep@gmail.com

Lịch sử

- Ngày nhận: 8-10-2020

- Ngày chấp nhận: 19-5-2021

- Ngày đăng: 25-5-2021

DOI : 10.32508/stdjet.v4i2.777

\section{Check for updates}

\section{Bản quyền}

๑) ĐHQG Tp.HCM. Đây là bài báo công bố mở được phát hành theo các điều khoản của the Creative Commons Attribution 4.0 International license.

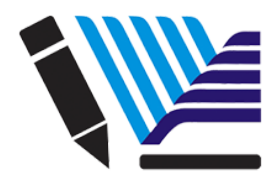

VNU-HCM Press
Trích dẫn bài báo này: Quân $L$, Nhật $V D$, Bách $P T$, Kỳ $N$ V. Ứng xử biến dạng của cọc hạt rời bọc vải địa kỹ thuật. Sci. Tech. Dev. J. - Eng. Tech.; 4(2):948-954. 